\title{
Effectiveness of Pugun Tanoh Leaves Ethanol Extract (Curanga fel-terrae (Lour.) Merr) as an Anti-inflammation in Patients after Tooth Extraction at Dental and Mouth Hospital of Dentistry Faculty, Universitas Sumatera Utara
}

\author{
Hendry Rusdy ${ }^{1 *}$, Marianne Marianne ${ }^{2}$, Baginda Mangatur Gurning ${ }^{1}$ \\ ${ }^{1}$ Department of Oral and Maxillofacial Surgery, Faculty of Dentistry, Universitas Sumatera Utara, Medan, Indonesia; ${ }^{2}$ Department \\ of Pharmacology, Faculty of Pharmacy, Universitas Sumatera Utara, Medan, Indonesia
}

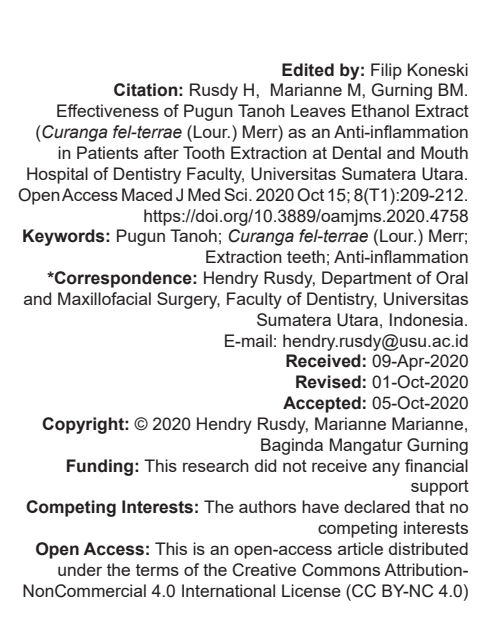

Introduction

The extraction of teeth causes injury to the soft tissue and hard tissue in the former extraction area [1]. Injuries that occur due to tooth extraction and/or surgery will experience a natural healing process by passing through the stages of the wound healing process. Basically, the stage is divided into 3, namely inflammation, proliferation, and remodeling [2]. This inflammation is characterized by local macroscopic changes in the presence of rubor, tumor, calor, dolor, and functio laesa [3]. Non-steroidal anti-inflammatory drugs and corticosteroids both have the ability to suppress signs and symptoms of inflammation. However, these two classes of drugs often cause adverse and harmful effects such as induction of gastric or peptic ulcer which is sometimes accompanied by anemia secondary to gastrointestinal bleeding and impaired platelet function due to inhibition of thromboxane $\mathrm{A} 2$ biosynthesis due to prolonged bleeding time, hepatotoxic, and nephrotoxic. The use of traditional medicine is a rational choice [4]. Curanga fel-terrae is one of the medicinal plants. C. fel-terrae grows in Asian regions such as China, India, Indonesia, Philippines, Malaysia, and Myanmar. In Indonesia, these plants are spread in Sumatra, Java, Kalimantan, and Maluku. C. fel-terrae often used by the Karo tribe of Tiga Lingga Village, Kabupaten Dairi, Provinsi Sumatera Utara to treat diarrhea, asthma, cough, scabies, inflammation, bruising, and abdominal pain [5]. C. fel-terrae has many benefits for treating various diseases not only empirically proven but also scientifically. Several studies conducted by Juwita et al. showed that ethanol extract of $C$. felterrae leaves was able to relax the tracheal smooth muscle so that it was thought that this extract could be used as asthma medications [6]. In 2014 and 2015, the 
study continued with hepatoprotective activity. It was proven that the ethanol extract of $C$. fel-terrae leaves at a dose of $125 \mathrm{mg} / \mathrm{kg}$ had hepatoprotective activity and had the same effect as catechins [7]. Acute toxicity, subchronic, and teratogenic tests have also been carried out so that the extract of $C$. fel-terrae leaves is safe for use in humans. Based on the acute toxicity test, there was no significant effect at a dose of $5000 \mathrm{mg} / \mathrm{kg}$ [8]. Based on the sub-chronic toxicity test for 90 days did not affect the hematological parameters of test animals [9]. Based on teratogen testing at a dose of $125 \mathrm{mg} / \mathrm{kg}$, there was a significant change in weight loss, fetal number, fetal weight and size, hemorrhage, retarded growth, increased number of resorption fetuses, and dead fetuses. Therefore, in this study, the extract of $C$. fel-terrae is not used in pregnant women [10]. Anti-inflammatory effect test ethanol extract of $C$. fel-terrae leaves on male mice given orally at a dose of $10 \mathrm{mg} / \mathrm{kg}$ provides the same statistically anti-inflammatory effect with indomethacin dose $10 \mathrm{mg} / \mathrm{kg}$ [4]. Based on the data above, the purpose of this study was to determine the effectiveness of $C$. fel-terrae leaves ethanol extract as an anti-inflammatory in patients after tooth extraction at Dental and Mouth Hospital of Dentistry Faculty, Universitas Sumatera Utara.

\section{Materials and Methods}

C. fel-terrae leaves ethanol extract that is already available from the USU Pharmacy lab was made by maceration method, carboxymethylcellulose (CMC), distilled water, glycerin, tampons (cotton wrapped in gauze becomes round), analytical balance, mortar and Stamford, $3 \mathrm{ml}$ syringe, visual analog scale (VAS) measuring instruments, Nirbeken, digital weight scales, USU Pharmacy laboratory glassware.

\section{Preparation of $0.5 \% \mathrm{CMC} \mathrm{Na}$}

$0.5 \%$ CMC NA is made to dissolve the ethanol extract of Pugun Tanoh leaves so that it becomes a preparation in the form of a suspension. A total of $0.5 \mathrm{~g}$ of $\mathrm{CMC} \mathrm{Na}$ powder are weighed then sprinkle into a mortar containing $10 \mathrm{ml}$ of distilled water, then cover and leave for 15 min until a transparent mass is obtained, crushed, and then diluted with distilled water and put into a $100 \mathrm{ml}$ measuring flask, add distilled water to the mark line.

\section{Preparation of C. fel-terrae leaves ethanol extract suspension}

In this study, the extract was made in the form of a suspension so that it can be easily applied to the tooth extraction socket. Preparation of suspension of C. fel-terrae leaves ethanol extract was carried out as follows: Weighing $2.31 \mathrm{~g}$ of $\mathrm{C}$. fel-terrae leaves ethanol

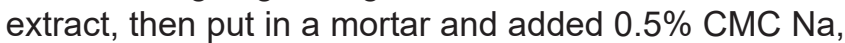

stirred until homogeneous then put in a $30 \mathrm{ml}$ measuring flask then add glycerin to the mark line.

\section{Data collection method}

1. This study was carried out in the Department of Oral and Maxillofacial Surgery, Faculty of Dentistry, Universitas Sumatera Utara. All the participants voluntarily participated in this study. Written consent was obtained from each individual. This study was ethically approved by the institutional ethical committee. The inclusion criteria of this study were patients extracting lower first molars and female patients who were not pregnant. While the exclusion criteria of this study were patients with tooth extraction with flap surgery and experienced complications after tooth extraction

2. Then, researchers measure the weight of patients with digital weight scales

3. The patient will then undergo a tooth extraction procedure that will be carried out by the clinical clerk student

4. The researcher prepared a suspension of ethanol extract of C. fel-terrae leaves $1.1 \mathrm{mg} / \mathrm{kg}$

5. For the treatment group, after the extracted teeth were given a suspension of ethanol extract of $C$. fel-terrae leaves $1.1 \mathrm{mg} / \mathrm{kg}$ on the tooth extraction socket using a $3 \mathrm{ml}$ syringe then instructed to bite the sterile tampon

6. In the control group, subjects were instructed to bite sterile tampons

7. Tampons will be bitten for 60 min after extraction after that the tampons are released in both groups

8. Both groups were given a complementary drug in the form of amoxicillin $500 \mathrm{mg}$ and mefenamic acid $500 \mathrm{mg}$. The instructions given to the patient are only required to take $500 \mathrm{mg}$ of amoxicillin as an antibiotic but for the $500 \mathrm{mg}$ mefenamic acid drug it is only instructed to drink it if there is pain that is felt by the patient

9. Measurements were made on the $1^{\text {st }}$ and $2^{\text {nd }}$ days after extracting using VAS to assess pain (dolor) and through direct observation to assess redness (rubor), heat (calor), and swelling (tumor).

\section{Results}

\section{value \\ Pain (dolor) distribution based on VAS}

The sample of the study based on the inclusion criteria was 36 people (Table 1). Distribution of pain (dolor) based on the value of VAS in the control group for the $1^{\text {st }}$ day, there were 2 patients with VAS 2 values, 3 patients with VAS 3 values, and so on. While in the 
Table 1: Distribution of research samples

\begin{tabular}{lll}
\hline Group & Amount & Percentage \\
\hline Treatment group & 18 & 50 \\
Control group & 18 & 50 \\
Amount & 36 & 100 \\
\hline
\end{tabular}

control group for the $2^{\text {nd }}$ day, there were 2 patients with VAS 1 values, 6 patients with VAS 2 values, and so on. In the treatment group for the $1^{\text {st }}$ day, the entirety of patients were with VAS value 0 . It was the same for the $2^{\text {nd }}$ day with VAS value 0 (Table 2 ).

Table 2: Distribution of VAS values for each group

\begin{tabular}{llllll}
\hline VAS value & \multicolumn{2}{l}{ Treatment group } & & \multicolumn{2}{l}{ Control group } \\
\cline { 2 - 3 } & Day 1 & Day 2 & & Day 1 & Day 2 \\
\hline 0 & 18 & 18 & & 0 & 0 \\
1 & 0 & 0 & 0 & 2 \\
2 & 0 & 0 & & 2 & 6 \\
3 & 0 & 0 & & 3 & 4 \\
4 & 0 & 0 & & 3 & 3 \\
5 & 0 & 0 & 10 & 3 \\
6 & 0 & 0 & 0 & 0 \\
7 & 0 & 0 & 0 & 0 \\
8 & 0 & 0 & 0 & 0 \\
9 & 0 & 0 & 0 & 0 \\
10 & 0 & 0 & 0 & 18 \\
Amount & 18 & 18 & 18 &
\end{tabular}

(severe pain). VAS: Visual analog scale.

Based on the data in Table 2, it can be seen that in the treatment group, all patients did not experience pain (dolor) after tooth extraction. While in the control group, all patients experienced pain (dolor) after tooth extraction. In the control group for the $1^{\text {st }}$ and $2^{\text {nd }}$ days, on average, patients experienced pain with a VAS score of 3.5278 with a standard deviation of 1.31987 . While in the treatment group, there were no patients who experienced pain. Then obtained the results of $p=0.000(p<0.05)$, it can be concluded that the ethanol extract of $C$. fel-terrae leaves has a significant effect in terms of preventing pain (dolor) on the examination of the $1^{\text {st }}$ and $2^{\text {nd }}$ days (Table 3 ).

Table 3: Statistical test results of t-test independent statistics on pain (dolor)

\begin{tabular}{lll}
\hline Group & Mean \pm SD & $p$ \\
\hline Treatment & $0.0000 \pm 0.0000$ & $0.000^{*}$ \\
Control & $3.5268 \pm 1.3198$ & \\
\hline Description: ${ }^{*}$ Significant relationship $(p<0.05)$. &
\end{tabular}

\section{Distribution of redness (rubor) marks on the first and second days}

All control group patients at the $1^{\text {st }}$ and $2^{\text {nd }}$ days after tooth extraction experienced signs of redness (rubor) while in the treatment group, patients did not experience redness on the $1^{\text {st }}$ day or the $2^{\text {nd }}$ day after tooth extraction (Table 4).

Table 4: Distribution of redness (rubor) marks on the $1^{\text {st }}$ and $2^{\text {nd }}$ days

\begin{tabular}{llllll}
\hline Redness (rubor) & \multicolumn{2}{l}{ Treatment group } & & Control group & \\
\cline { 2 - 3 } & Day 1 & Day 2 & & Day 1 & Day 2 \\
\hline Have & 0 & 0 & & 18 & 18 \\
Not have & 18 & 18 & & 0 & 0 \\
\hline
\end{tabular}

Based on the results of the Chi-square statistical test can be obtained $p=0.000(p<0.05)$, it can be concluded that the ethanol extract of $C$. fel-terrae leaves has a significant effect in terms of preventing the sign of redness (rubor) in patients after tooth extraction (Table 5).
Table 5: Chi-square statistical test results on the sign of redness (rubor)

\begin{tabular}{llll}
\hline Redness mark (rubor) & Treatment group & Control group & $\mathrm{p}$ \\
\hline Have & 0 & 18 & $0.000^{*}$ \\
Not have & 18 & 0 & \\
\hline Description: *Significant relationship $(\mathrm{p}<0.05)$. & &
\end{tabular}

\section{Distribution of heat (calor) on the $1^{\text {st }}$ and $2^{\text {nd }}$ days}

All control group patients at the $1^{\text {st }}$ and $2^{\text {nd }}$ days after tooth extraction experienced heat (calor) while in the treatment group, patients did not experience heat (calor) on the $1^{\text {st }}$ day or the $2^{\text {nd }}$ day after tooth extraction (Table 6). Based on the results of the Chi-square

Table 6: Distribution of heat (calor) on the $1^{\text {st }}$ and $2^{\text {nd }}$ days

\begin{tabular}{llllll}
\hline Heat (calor) & Treatment group & & & Control group & \\
\cline { 2 - 3 } & Day 1 & Day 2 & & Day 1 & Day 2 \\
\hline Have & 0 & 0 & & 18 & 18 \\
Not have & 18 & 18 & & 0 & 0 \\
\hline
\end{tabular}

statistical test can be obtained $p=0.000(p<0.05)$, it can be concluded that the ethanol extract of $C$. fel-terrae leaves has a significant influence in terms of preventing heat (calor) in patients after tooth extraction (Table 7).

Table 7: Chi-square statistical test results on heat (calor)

\begin{tabular}{llll}
\hline Heat $($ calor $)$ & Treatment group & Control group & $\mathrm{p}$ \\
\hline Have & 0 & 18 & $0.000^{*}$ \\
Not have & 18 & 0 & \\
\hline Description: ${ }^{*}$ Significant relationship $(p<0.05)$. & &
\end{tabular}

\section{Distribution of swelling (tumor) on the $1^{\text {st }}$ and $2^{\text {nd }}$ days}

All control group patients on examination of the $1^{\text {st }}$ and $2^{\text {nd }}$ days after tooth extraction experienced swelling (tumor) while in the treatment group, patients did not experience swelling (tumor) on the $1^{\text {st }}$ day or the $2^{\text {nd }}$ day after tooth extraction (Table 8). Based on the Table 8: Distribution of swelling (tumor) on the $1^{\text {st }}$ and $2^{\text {nd }}$ days

\begin{tabular}{llllll}
\hline Swelling (tumor) & \multicolumn{2}{l}{ Treatment group } & & \multicolumn{2}{l}{ Control group } \\
\cline { 2 - 3 } & Day 1 & Day 2 & & Day 1 & Day 2 \\
\hline Have & 0 & 0 & & 18 & 18 \\
Not have & 18 & 18 & & 0 & 0 \\
\hline
\end{tabular}

results of the Chi-square statistical test can be obtained $p=0.000(p<0.05)$, it can be concluded that the ethanol extract of $C$. fel-terrae leaves has a significant effect in preventing swelling (tumor) in patients after tooth extraction (Table 9).

Table 9: Chi-square statistic test results on swelling (tumor)

\begin{tabular}{llll}
\hline Swelling (tumor) & Treatment gr oup & Control group & $\mathrm{p}$ \\
\hline Have & 0 & 18 & $0.000^{*}$ \\
Not have & 18 & 0 & \\
\hline Description: ${ }^{*}$ Significant relationship $(p<0.05)$. & &
\end{tabular}

\section{Discussion}

Based on the research that has been done, it was found that there was a difference between the treatment groups given ethanol extract of $C$. fel-terrae leaves and the control group which was not given ethanol 
extract of $C$. fel-terrae leaves. The treatment group which was given ethanol extract of $C$. fel-terrae leaves did not have signs of inflammation both on the $1^{\text {st }}$ and $2^{\text {nd }}$ days after tooth extraction, while the control group which was not given ethanol extract of $C$. fel-terrae leaves had signs of inflammation both on the $1^{\text {st }}$ day and the $2^{\text {nd }}$ day after tooth extraction. It can be concluded that the ethanol extract of C. fel-terrae leaves is effectively used as an antiinflammatory in patients after tooth extraction. The results of this study are similar to the previous research conducted by Juwita in 2009 in male mice. The results of statistical tests were performed using independent t-test statistics to assess pain (dolor) and Chi-square statistical tests to assess signs of redness (rubor), feeling of heat (calor), and swelling (tumor) showed a significant difference between groups the treatment was given ethanol extract of $C$. felterrae leaves and the control group which was not given ethanol extract of $C$. fel-terrae leaves. The pain sensation experienced by each individual varies depending on emotional conditions and previous emotional experiences, so in the control group, there was a difference in pain (dolor) [11]. Ethanol extract of C. fel-terrae leaves contains flavonoids, tannins, glycosides, saponins, and steroids/triterpenoids [6]. Compounds that have antiinflammatory effects are flavonoids, tannins, and steroids/ triterpenoids. Steroid/triterpenoid compounds have antiinflammatory effects because can inhibit the enzymatic work of phospholipase, thus preventing the release of inflammatory mediators, namely, arachidonic acid and its metabolites such as prostaglandins, leukotrienes, prostacyclin, and thromboxane [4]. Based on Sukmawati et al. research in 2015 , flavonoids in the body inhibit the lipo-oxygenase enzyme that plays a role in leukotriene biosynthesis. Flavonoids also inhibit the secretion of lysosomal enzymes which are inflammatory mediators which inhibit the proliferation of the inflammatory process. Tannin has the potential as anti-inflammatory because it has antioxidant activity, so it inhibits reactive oxidants such as hydroxy $(\mathrm{OH})$ radicals and hypochlorous acid either directly or through inhibition of the production of oxidants $\left(\mathrm{O}_{2}\right)$ by neutrophils, monocytes, and macrophages [12].

\section{Conclusion}

C. fel-terrae leaves ethanol extract is effective to be used as an anti-inflammatory in patients after tooth extraction combined with amoxicillin $500 \mathrm{mg}$ and mefenamic acid $500 \mathrm{mg}$.

\section{Acknowledgment}

The authors are very thankful to the head of the Dental and Mouth Hospital of Dentistry Faculty,
Universitas Sumatera Utara and the head of the Department of Pharmacology, Faculty of Pharmacy, Universitas Sumatera Utara for providing facilities to conduct our experimental work.

\section{Authors' Contributions}

Dr. Hendry Rusdy has supervised the experiment and reviewed the article. Marianne $M$. Si gave the concept and design of this study. All the practical work was done by Baginda Mangatur Gurning. The writing and editing were done by Dr. Hendry Rusdy, Marianne M. Si, and Baginda Mangatur Gurning.

\section{References}

1. Larjava H. Oral Wound Healing: Cell Biology and Clinica Management. Chicester: Wiley Blackwell; 2012. p. 195-203.

2. Andersson L, Kahnberg KE, Pogrel MA. Oral and Maxillofacial Surgery. $1^{\text {st }}$ ed. Oxford: Wiley Blackwell; 2010. p. 165-9.

3. Asija R, Prajapat R, Vyas P, Kumar P. A brief cause of acute inflammation: An Overview. J Drug Discov Ther. 2014;2(22):31-5.

4. Juwita NA. Karakteristik Simplisia dan Uji Efek Antinflamasi Ekstrak Etanol Daun Pugun Tanoh (Curanga fel-terrae Merr.) Terhadap Mencit Jantan. Skripsi. Medan: E-repository Universitas Sumatera Utara; 2009. p. 1-54.

5. Harahap U, Husori DI, Marianne M, Yuliasmi S, Patilaya P, Laila $\mathrm{L}$, et al. Inhibitory effect of ethanolic extract of Curanga fel-terrae (Pugun tano) leaves on acetylcholine muscarinic-3 receptors induced on isolated guinea pig tracheal. Asian J Pharm Clin Res. 2017;10:95-8. https://doi.org/10.22159/ajpcr.2017.v10i1.14163

6. Juwita NA, Harahap $U$, Dalimunthe A. Relaxation effect of ethanolic extract of Picria fel-terrae (Pugon tanoh) leaves on contraction of isolated rat's ileum contracted by serotonin. $J$ Innov Pharm Biol Sci. 2018;5(1):37-41.

7. Marianne A, Chrestella J, Ginting MA, Dalimunthe A, Nasution R. Hepatoprotective activity combination of Curanga fel-terrae Lour leaves and Curcuma heyneana valeton and zijprhizome in rat induced by combination of rifampin and isoniazid. Int JPharm Pharm Sci. 2017;9(5):23-8. https://doi.org/10.22159/ijpps.2017v9i5.16528

8. Patilaya P, Husori DI, Sumantri IB, Sihombing S. Acute toxicity study of the leaves ethanolic extract of picria fel-terrae Lour. Asian J Pharm Clin Res. 2018;11(13):55-8. https://doi. org/10.22159/ajpcr.2018.v11s1.26567

9. Harahap U. Subchronic toxicity evaluation of ethanol extract of picria fel-terrae Lour. leaf in wistar rats. Sci Pharm. 2018;86(3):34. https://doi.org/10.3390/scipharm86030034

10. Fawziah R. Teratogenic Effects of Ethanol Extract of Pugun Tanoh (Picria fel-terrae Lour.) Leaf Extract on Female Rats, Thesis. Medan: University of North Sumatra E-Repository; 2018. p. 1-57.

11. Ulfa NN. The effectiveness of paracetamol for postoperative pain was assessed on a visual analog scale. J M Med Mud. 2014:1-10

12. Sukmawati $S$, Yuliet $Y$, Hardani R. Anti-inflammatory activity test of ethanolic extract of banana leaf (Musa paradisiaca L.) on carrageenan-induced paw edema in white rats (Rattus norvegicus L.). J Pharm Galen 2015;1(2):126-32. 